\title{
PARTNERSTWO NA RZECZ MOBILNOŚCI JAKO INSTRUMENT POLITYKI IMIGRACYJNEJ UNII EUROPEJSKIEJ
}

\section{WPROWADZENIE}

Wydarzenia 2015 r. związane ze wzmożonym napływem migrantów na terytorium Unii Europejskiej (UE) spowodowały wzrost zainteresowania polityką imigracyjna. Niestabilna sytuacja polityczna w Syrii, Afganistanie i Erytrei sprawiła, że setki tysięcy mieszkańców zagrożonych regionów zdecydowało się opuścić swoje domy i ruszyć w poszukiwaniu lepszych warunków życia. Wielu z nich udało się w niebezpieczną podróż do Europy, wielu tej podróży nie przeżyło. Unia Europejska nie była gotowa, by stawić czoła takiej liczbie migrantów, z których w rzeczywistości tylko część stanowili uchodźcy. Komisja Europejska starała się szybko reagować (m.in. przygotowujacc 10-punktowy plan natychmiastowych działań, program przesiedleń i relokacji ${ }^{1}$ ), jednakże jej skuteczność jest różnie oceniana ${ }^{2}$. UE oraz politycy państw członkowskich ostatnich kilkanaście miesięcy spędzili na poszukiwaniu skutecznych rozwiązań kryzysu migracyjnego. W tym kontekście Komisja Europejska przypomina swoje, promowane od 2000 r., stanowisko, w którym podkreśla konieczność efektywnej współpracy w dziedzinie migracji z krajami trzecimi w celu skutecznego zapobiegania nielegalnej imigracji do $\mathrm{UE}^{3}$.

Zadaniem niniejszego artykułu jest m.in. przybliżenie realizowanych w ramach europejskiej polityki imigracyjnej partnerstw na rzecz mobilności oraz analiza ich założeń zawartych w dokumentach instytucji UE. Partnerstwo to niewiążąca umowa, zawierana pomiędzy zainteresowanymi państwami członkowskimi Unii Europejskiej i krajami trzecimi, której celem jest szeroko pojęta współpraca w zarządzaniu migracjami. W artykule szczególny nacisk został położony na mobilność, czyli wspieranie legalnej migracji obywateli państw trzecich do krajów UE. Ponadto jednym z priorytetów przyświecajacych publikacji jest ewaluacja zawartych deklaracji oraz próba oceny ich wpływu na zwiększenie mobilności do państw członkowskich.

\footnotetext{
${ }^{1}$ Komisja Europejska, Europejski program w zakresie migracji, $\mathrm{COM}(2015) 240$.

2 T. Morozowski., Działania Komisji Europejskiej wobec kryzysu migracyjnego, Instytut Zachodni, https://pl.boell.org/pl/2016/03/01/dzialania-komisji-europejskiej-wobec-kryzysu-migracyjnego [dostęp: 27.01.2017]; A. Potyrała, W poszukiwaniu solidarności. Unia Europejska wobec kryzysu migracyjnego 2015, „Przegląd Politologiczny” 2015, nr 4.

${ }^{3}$ European Commission, A common policy on legal illegal migration, $\operatorname{COM}(2001) 672$.
} 
W pierwszej części artykułu przedstawiony został kontekst, w jakim powstała polityka imigracyjna UE. We fragmentach poświęconych analizie dokumentów urzędowych Unii Europejskiej, w szczególności komunikatów Komisji Europejskiej oraz konkluzji Rady Europejskiej, wykorzystano metodę dogmatyczną. Następnie szczegółowej charakterystyce i analizie prawnoporównawczej poddane zostały teoretyczne założenia partnerstw na rzecz mobilności, które w dalszej części zostały skonfrontowane z faktycznymi postanowieniami podpisanych deklaracji. Analiza danych statystycznych pochodzących z Eurostatu i bazy OECD stanowi źródło informacji dotyczących wstępnych zmian w liczbie napływajacych do poszczególnych państw członkowskich obywateli państw trzecich pochodzacych z krajów, które jako pierwsze podpisały partnerstwa na rzecz mobilności.

Przeprowadzone badania oraz krytyczna ocena materiałów źródłowych, głównie literatury przedmiotu, umożliwiły ewaluację przyjętych partnerstw na rzecz mobilności oraz wskazanie pozytywnych i negatywnych elementów przyjętych umów; pozwoliły ponadto na odpowiedź na pytanie, w jakim stopniu istniejace deklaracje mają szansę przyczynić się do promowania legalnej migracji do państw UE będących stroną umów. W artykule wykorzystano liczne publikacje naukowe oraz dane statystyczne Eurostatu i OECD. Cytowana literatura w zdecydowanej większości pochodzi ze źródeł anglojęzycznych, co wynika $\mathrm{z}$ faktu, że niewiele uwagi poświęcono omawianej problematyce w rodzimych publikacjach.

\section{ROZWÓJ POLITYKI IMIGRACYJNEJ UNII EUROPEJSKIEJ}

Unia Europejska dość późno zyskała kompetencje w dziedzinie polityki imigracyjnej. Traktaty rzymskie nie zawierały żadnych postanowień odnośnie do przepływu obywateli państw trzecich ${ }^{4}$. Asumptem do podjęcia działań w tym zakresie było utworzenie strefy Schengen i wspólnego rynku. W celu zapewnienia bezpieczeństwa swoim obywatelom obszar UE, pozbawiony granic wewnętrznych i gwarantujaccy swobodę przepływu kapitału, towaru, usług i przede wszystkim osób - nie mógł dłużej funkcjonować bez wspólnych regulacji w zakresie imigracji. Pierwsze, dość ograniczone kompetencje w tej dziedzinie UE zyskała w chwili wejścia w życie traktatu z Maastricht. W utworzonej wówczas trójfilarowej strukturze Unii kwestie związane z azylem i imigracja zostały umieszczone w III filarze: Wymiar sprawiedliwości i spraw wewnętrznych, opartym na współpracy międzyrządowej ${ }^{5}$. W art. K.1 Traktatu polityka imigracyjna i polityka dotycząca obywateli państw trzecich zostały uznane za przedmiot wspólnego zainteresowania. Dopiero w 1997 r. w wyniku podpisania traktatu z Amsterdamu dziedzina ta została przeniesiona do I fila-

${ }^{4}$ C. Balleix, La politique migratoire de l'Union europeenne, La documentation Française, Paris 2013, s. 7.

${ }^{5}$ H. Wallace, W. Wallace, Policy-making in the European Union, OUP, Oxford 2005, s. 461. 
ru i została objęta reżimem unijnym ${ }^{6}$. Rezultatem „uwspólnotowienia” polityki migracyjnej były działania podejmowane w sferze unijnej polityki oraz wzmożona aktywność ustawodawcza w zakresie legalnej migracji ${ }^{7}$. Przyjęcie w grudniu 2007 r. traktatu z Lizbony potwierdziło zaangażowanie UE w sprawy zwiąane z polityką migracyjna, która uznana została za kompetencję dzieloną między Unię i państwa członkowskie. Zgodnie z art. 79 TUE:

Unia rozwija wspólną politykę imigracyjną mającą na celu zapewnienie, na każdym etapie, skutecznego zarządzania przepływami migracyjnymi, sprawiedliwego traktowania obywateli państw trzecich przebywających legalnie w państwach członkowskich $[\ldots]^{8}$.

Współpraca w ramach polityki imigracyjnej przeszła stopniową ewolucję. Początkowo sfera ta należała wyłącznie do kompetencji państw członkowskich i opierała się na kooperacji międzyrządowej, gdzie wykorzystywane były głównie instrumenty prawne w postaci aktów typu soft law. Jednak pojawienie się nowych zjawisk o międzynarodowym charakterze spowodowało zacieśnianie współpracy pomiędzy państwami członkowskimi. Obecnie dziedzina ta opiera się już na kooperacji na poziomie wspólnotowym.

\section{PARTNERSTWO NA RZECZ MOBILNOŚCI}

W grudniu 2005 r. Rada Europejska przyjęła tzw. globalne podejście do migracji, zakładające szeroką współpracę pomiędzy państwami członkowskimi UE a krajami, z których pochodzi największa część imigrantów ${ }^{9}$. Globalne podejście ma na celu połączenie wszystkich strategii politycznych odnoszacych się do migracji w bardziej spójny sposób. Celem współpracy z państwami trzecimi jest wzmacnianie synergii pomiędzy rozwojem i migracja, zidentyfikowanie wspólnych wyzwań i interesów, szczególnie w zakresie lepszej organizacji migracji legalnej, ułatwienia mobilności oraz zapobieganie i redukcja nieregularnej migracji. Kluczowym instrumentem mającym sprzyjać realizacji globalnego podejścia do migracji sa partnerstwa na rzecz mobilności zawierane pomiędzy UE a krajami trzecimi ${ }^{10}$. W wyniku wzmożonego napływu imigrantów do państw członkowskich w czasie arabskiej wiosny Komisja Europejska zaproponowała nowe globalne podejście do kwestii migracji i mobilności, które skupia się na migracji obywateli państw trzecich i sprawia, że partnerstwa będą trwalsze i bardziej nastawione na przyszłośćc ${ }^{11}$.

${ }^{6}$ E. Borawska-Kędzierska, K. Strąk, Przestrzeń Wolności, Bezpieczeństwa i Sprawiedliwości. Zarzadzanie granicami, polityka wizowa, azylowa i imigracyjna, Instytut Wydawniczy EuroPrawo, Warszawa 2011, s. 10.

${ }^{7}$ Szerzej w: I. Wróbel, Wspólnotowe prawo imigracyjne, Wolters Kluwer Polska, Warszawa 2008, s. 35-55.

${ }^{8}$ Traktat o Unii Europejskiej, Dz. Urz. UE C 306 z 17 grudnia 2007 r.

${ }^{9}$ Rada Europejska, Wnioski Prezydencji, 15-16 grudnia 2005 r., Szczyt Rady Europejskiej w Hampton Court, s. 2.

${ }^{10}$ Komisja Europejska, Podejście globalne do migracji w rok później: ku kompleksowej europejskiej polityce migracyjnej, $\operatorname{COM}(2006) 735$.

${ }^{11}$ Komisja Europejska, Globalne podejście do kwestii migracji, $\mathrm{COM}(2011) 743$. 
Zgodnie z komunikatem opublikowanym w 2007 r. partnerstwa na rzecz mobilności mają służyć efektywnemu zarządzaniu przepływami migracyjny$\mathrm{mi}^{12}$. UE chce w ten sposób utworzyć ramy dialogu i współpracy z państwami znajdującymi się $\mathrm{w}$ bezpośrednim sasiedztwie oraz z krajami, których obywatele od dawna napływają na terytorium UE (np. Maroko, Tunezja, Egipt). $\mathrm{W}$ praktyce ma to być

oferta kilku państw członkowskich dotycząca łatwiejszego dostępu do ich rynków pracy dla obywateli danych krajów trzecich. [...] Poszczególne oferty byłyby zebrane w jeden pakiet i przedstawiane krajowi trzeciemu jako całościowa oferta $\mathrm{UE}^{13}$.

Partnerstwa na rzecz mobilności są instrumentem mającym złożony charakter prawny z tego względu, że ich postanowienia nie zawsze wchodzą w zakres uprawnień UE. Niektóre elementy partnerstw należą do kompetencji państw członkowskich. Mimo że zgodnie z postanowieniami traktatu z Amsterdamu wiele spraw związanych z polityką azylową i migracyjną zostało „uwspólnotowionych", decyzja co do przyjęcia na terytorium państw członkowskich migrantów zarobkowych pozostaje kompetencją krajową (art. 79 TfUE). Treść postanowień, jakie państwa zobowiązują się na siebie przyjać, podlega negocjacji; partnerstwa są „dostosowane do szczególnych warunków panujących w danym kraju trzecim i jego aspiracji, jak również zamiarów UE, oraz do poziomu zobowiązań, jakie kraj trzeci jest gotowy podjąc w zakresie zwalczania nielegalnej migracji i ułatwiania ponownej integracji powracajaccych migrantów, w tym stwarzania możliwości zatrudnienia"14.

W cytowanym komunikacie Komisji zawartych jest jednak kilka elementów, jakie mogą znaleźć się w treści partnerstw na rzecz mobilności. Są to zarówno zobowiąania państw trzecich, jak i państw członkowskich. W'śród postulatów, jakie powinny spełnić państwa trzecie, znajdujemy m.in. skuteczną readmisję własnych obywateli i współpracę w ustalaniu ich tożsamości oraz w określonych okolicznościach readmisję obywateli państw trzecich i bezpaństwowców, którzy przybyli do UE przez terytorium danego państwa trzeciego. Ponadto kraje trzecie powinny podejmować inicjatywy służące zmniejszeniu skali nielegalnej imigracji, usprawnieniu kontroli na granicach oraz lepszemu zabezpieczeniu dokumentów podróży przed fałszowaniem. Równie istotne jest skuteczne zwalczanie zjawiska przemytu i handlu ludźmi. W celu likwidacji nielegalnej imigracji od partnerów UE można wymagać również zobowiązania do poprawy swojej sytuacji ekonomiczno-społecznej. Realizacja partnerstw zakłada całkowite poszanowanie podstawowych praw jednostek oraz przewiduje pomoc finansowa i techniczną oferowana państwom trzecim ${ }^{15}$. Z drugiej strony państwa członkowskie zobowiąują się do wprowadzenia „mechanizmów ułatwiania migracji zarobkowej, które powinny odnosić się do potrzeb rynku pracy zainteresowanych państw członkowskich, zgodnie z oceną tych państw, przy pełnym poszanowaniu zasady

12 Komisja Europejska, Komunikat w sprawie migracji wahadtowej i partnerstw na rzecz mobilności między Unia Europejska a krajami trzecimi, COM(2007)248, s. 9-10.

13 Ibidem.

14 Ibidem, s. 4.

15 Ibidem, s. 4-5. 
preferencji wspólnotowej w odniesieniu do obywateli UE"16. Odpowiednio sformułowane zapisy mogą zapobiegać zjawisku drenażu mózgów, czyli odpływowi wykształconych obywateli. Państwa członkowskie powinny również podjąć działania w celu usprawnienia procedury wydawania obywatelom państw trzecich wiz krótkoterminowych, co powinno przyczynić się do wzrostu zainteresowania legalnymi formami migracji.

Partnerstwa na rzecz mobilności nie muszą ograniczać się do kwestii związanych z migracją i ochroną granic. Wręcz przeciwnie, dobre umowy powinny obejmować szereg innych dziedzin współpracy z państwami trzecimi, m.in. w sferze zatrudnienia, polityki społecznej, edukacji czy szkoleń. Takie kompleksowe porozumienie jest z pewnością trudniejsze do osiagnięcia, ale może przynieść zdecydowanie większe korzyści. Komisja zauważa, że „rozwinięcie partnerstw na rzecz mobilności wymaga sprawniejszej koordynacji i bliższej współpracy między Komisją a państwami członkowskimi w celu zapewnienia maksymalnej synergii między działaniami na obu poziomach, bez naruszania właściwych kompetencji stron"17.

Przystapienie państw członkowskich do partnerstw z poszczególnymi krajami trzecimi nie jest obowiązkowe, a ich treść nie ma charakteru prawnie wiążącego. Parlament Europejski pozbawiony jest wpływu na proces tworzenia i przyjmowania partnerstw, a ich postanowienia, ze względu na brak mocy prawnie wiążącej, nie podlegają jurysdykcji Trybunału Sprawiedliwości UE. Negocjacje i implementację partnerstw ze strony UE koordynuje Komisja Europejska. Następnie instytucja ta monitoruje realizację zawartych w nich inicjatyw. Państwa członkowskie angażują agencje rządowe, które w porozumieniu z odpowiednimi instytucjami państw partnerskich implementuja postanowienia zawartych deklaracji.

\section{PARTNERSTWO NA RZECZ MOBILNOŚCI W PRAKTYCE}

Pierwsze umowy partnerstwa na rzecz mobilności zostały podpisane w 2008 r. z Mołdawią i Republiką Zielonego Przylądka ${ }^{18}$. Oba dokumenty będące wzorcem dla pozostałych umów przewidują promowanie rozwiązań mających wspierać legalna migrację przy jednoczesnym redukowaniu nielegalnych przepływów ludności. Warto jednak podkreślić, że najnowsze partnerstwa (z Jordania, Tunezją oraz Białorusia) nie zawierają już aneksów wyszczególniających konkretne inicjatywy proponowane przez poszczególne państwa czy Komisję Europejska. Historię partnerstw na rzecz mobilności przedstawiono w tabeli 1.

\footnotetext{
16 Ibidem, s. 5.

17 Ibidem, s. 16.

${ }^{18}$ Council of the European Union, Joint Declaration on a Mobility Partnership between the European Union and the Republic of Moldova, 9460/08 ADD 1, Brussels 2008, Council of the European Union, Joint Declaration on a Mobility Partnership between the European Union and the Republic of Cape Verde, 9460/08 ADD 1, Brussels 2008.
} 
Tabela 1

\begin{tabular}{|c|l|l|}
\hline Data & \multicolumn{1}{|c|}{ Kraj partnerski } & \multicolumn{1}{c|}{ Kraje członkowskie UE } \\
\hline 2008 & Mołdawia & $\begin{array}{l}\text { Bułgaria, Cypr, Czechy, Francja, Niemcy, Grecja, Węgry, } \\
\text { Włochy, Litwa, Polska, Portugalia, Rumunia, Słowacja, } \\
\text { Słowenia, Szwecja }\end{array}$ \\
\hline 2008 & $\begin{array}{l}\text { Republika Zielonego } \\
\text { Przylądka }\end{array}$ & Hiszpania, Francja, Luksemburg, Portugalia \\
\hline 2009 & Gruzja & $\begin{array}{l}\text { Belgia, Bułgaria, Czechy, Dania, Niemcy, Estonia, Gre- } \\
\text { cja, Francja, Włochy, Litwa, Łotwa, Holandia, Polska, } \\
\text { Rumunia, Szwecja, Wielka Brytania }\end{array}$ \\
\hline 2011 & Armenia & $\begin{array}{l}\text { Belgia, Bułgaria, Czechy, Niemcy, Francja, Włochy, Ho- } \\
\text { landia, Polska, Rumunia, Szwecja }\end{array}$ \\
\hline 2013 & Maroko & $\begin{array}{l}\text { Belgia, Francja, Niemcy, Włochy, Holandia, Portugalia, } \\
\text { Hiszpania, Szwecja, Wielka Brytania }\end{array}$ \\
\hline 2013 & Azerbejdżan & $\begin{array}{l}\text { Bułgaria, Czechy, Francja, Litwa, Holandia, Polska, } \\
\text { Słowacja, Słowenia }\end{array}$ \\
\hline 2014 & Jordania & $\begin{array}{l}\text { Cypr, Dania, Niemcy, Grecja, Hiszpania, Francja, Wło- } \\
\text { chy, Węgry, Polska, Portugalia, Rumunia, Szwecja }\end{array}$ \\
\hline 2015 & Tunezja & $\begin{array}{l}\text { Belgia, Niemcy, Dania, Hiszpania, Włochy, Francja, } \\
\text { Polska, Portugalia, Wielka Brytania, Szwecja }\end{array}$ \\
\hline Białoruś & $\begin{array}{l}\text { Bułgaria, Litwa, Łotwa, Finlandia, Polska, Rumunia, } \\
\text { Węgry }\end{array}$ \\
\hline
\end{tabular}

Źródło: opracowanie własne.

Partnerstwa rozpoczynają się bardzo podobną preambułą nawiązująca do istniejących form współpracy pomiędzy krajami członkowskimi i krajami partnerskimi oraz do kluczowych dokumentów UE traktujacych o migracji (m.in. do komunikatów Komisji Europejskiej i konkluzji Rady). We wstępie pojawia się zobowiązanie stron do ułatwiania przepływu ludności i lepszego zarządzania ruchami migracyjnymi, w tym walki z nielegalną imigracją. Postanowienia pierwszych partnerstw koncentruja się wokół trzech głównych tematów: mobilność, legalna migracja i integracja; migracja i rozwój; zarządzanie granicami, dokumenty osób podróżujących oraz walka z nielegalną migracją i przemytem ludzi. Partnerstwo z Armenią zapoczątkowało współpracę w ramach ochrony międzynarodowej i azylu ${ }^{19}$. Każda kategoria zawiera kilka bardziej szczegółowych założeń umawiajacych się stron.

W ramach pierwszej grupy działań zakłada się m.in. zwiększenie możliwości instytucjonalnych państw partnerskich w zakresie migracji, rzetelne informowanie potencjalnych migrantów o możliwościach legalnej pracy, ogólnych warunkach życia w krajach członkowskich i ryzyku związanym z nielegalnym przyjazdem i zatrudnieniem w UE oraz zapewnienie migrantom ochrony socjalnej. Druga kategoria obejmuje postanowienia dotyczace wsparcia reintegracji powracających pracowników, informowania migrantów o sytuacji na

${ }^{19}$ Council of the European Union, Joint Declaration on a Mobility Partnership between the European Union and Armenia, 14963/11 ADD 1, Brussels 2011. 
rynku pracy i możliwościach zatrudnienia w kraju ojczystym oraz podjęcia działań niwelujących zjawisko drenażu mózgów i wzmocnienia stosunków z diaspora. W ramach walki z nielegalna imigracją główne postanowienia koncentrują się wokół odpowiedniej kontroli granic i lepszego zabezpieczania dokumentów osób podróżujących. Kraje partnerskie zobowiązują się do ścisłej współpracy z Europejską Agencją Straży Granicznej i Przybrzeżnej (FRONTEX) oraz Europejską Fundacją Kształcenia (European Training Foundation) w zakresie readmisji i powrotu swoich obywateli. Współpraca w dziedzinie azylu i ochrony międzynarodowej koncentruje się wokół konieczności wzmocnienia zdolności rządów państw partnerskich do wdrożenia polityki azylowej i zapewnienia ochrony międzynarodowej zgodnie z najlepszymi standardami międzynarodowymi.

Deklaracje zawierają również zapisy dotyczące praktycznej realizacji umów partnerstwa na rzecz mobilności. Umowy te sa uważane za długoterminową formę współpracy opartą na dialogu politycznym, która będzie ewoluowała z czasem. Przewidziane są regularne spotkania (dwa razy do roku) na odpowiednim szczeblu, których celem będzie rewizja priorytetów partnerstw i ich ocena. Partnerstwa zapowiadają realizację inicjatyw mających na celu maksymalizację korzystnego wpływu migracji na rozwój państw trzecich poprzez m.in. zachęcanie do transferów finansowych przekazywanych przez migrantów oraz wspieranie cyrkulacji i powrotu zagranicznych pracowników do krajów ojczystych. Istotnym elementem jest również zapowiedź wprowadzenia mechanizmu monitorującego przepływ ludności oraz oceniającego wpływ migracji na krajowy rynek pracy. Ostatnią częścią partnerstw jest aneks zawierający propozycje konkretnych działań mających doprowadzić do realizacji założeń zawartych w umowach. Poszczególne projekty są inicjatywą uczestniczących w partnerstwie stron - państw członkowskich, kraju partnerskiego, Komisji Europejskiej lub kilku wyżej wymienionych aktorów.

Jeżeli chodzi o postanowienia wspierające legalną migrację do państw członkowskich we wszystkich umowach można odnotować postanowienia dotyczace konieczności skutecznego informowania potencjalnych migrantów o możliwościach zatrudnienia i warunkach życia w państwach UE oraz o zagrożeniach płynących z nielegalnej migracji. W tym celu proponuje się m.in. współpracę z europejskim portalem zatrudnienia, seminaria i wymianę informacji pomiędzy instytucjami i organami odpowiedzialnymi za zarządzanie przepływami ludności, a nawet przygotowanie dla potencjalnych migrantów podręcznika zawierajacego szereg istotnych informacji odnośnie do pobytu i zatrudnienia w państwach UE. Zakłada się ponadto wsparcie ze strony państw członkowskich dla wszelkich instytucji i ich pracowników, w tym agencji zatrudnienia i organów państwowych, które zaangażowane są w zarządzanie migracjami. W partnerstwach pojawiają się również propozycje wprowadzenia ułatwień wizowych dla migrujacych pracowników, programów pracy tymczasowej i cyrkulacji migrantów oraz ułatwień w uznawaniu kwalifikacji zawodowych i akademickich obywateli państw partnerskich. Szczególną uwagę poświęcono studentom i absolwentom, którym zaproponowano różnego rodzaju formy mobilności do UE. Przewiduje się również współpracę ośrodków akademickich 
w celu wymiany studentów i pracowników naukowych. W wielu partnerstwach pojawia się zapowiedź organizowania dla przyszłych migrantów specjalnych kursów dotyczących procedur wjazdu i środków integracji w państwach przyjmujących, mających przygotować ich do pobytu i pracy w UE jeszcze przed wyjazdem.

Całościowa analiza umów partnerstwa wyraźnie pokazuje, że podpisane deklaracje skupiają się głównie na dwóch aspektach - na wzmocnionej kontroli granic oraz na walce $\mathrm{z}$ nielegalną imigracją. Zwraca się uwagę, że państwom członkowskim bardziej niż na zwiększeniu legalnej mobilności obywateli państw trzecich zależy na większej kontroli przepływów ludności, czy wręcz na ich ograniczaniu ${ }^{20}$. Migracja ekonomiczna, prawa migrantów czy wzajemne rozpoznawanie kwalifikacji pracowników zostały odsunięte na dalszy plan, a kwestie związane z łączeniem rodzin czy integracją migrantów w państwach członkowskich prawie zupełnie pominięto. Rezygnacja z postanowień dotyczących migracji zarobkowej była zapewne wynikiem braku kompetencji UE w pewnych sferach państwa członkowskie nie wyraziły zgody na przekazanie organizacji uprawnień w dziedzinie migracji ekonomicznej, która pozostaje sferą należąca do kompetencji państw członkowskich. Jest to jeden z powodów, dla których partnerstwa na rzecz mobilności z jednej strony nie koncentrują się na regulacjach w zakresie migracji zarobkowej, a z drugiej pozbawione zostały mocy wiążącej.

\section{EWALUACJA PARTNERSTWA NA RZECZ MOBILNOŚCI}

Komisja Europejska jest przekonana o efektywności umów partnerstwa na rzecz mobilności i wskazuje, że brak mocy wiążacej deklaracji sprawia, że ich przyjęcie nie jest tak czasochłonne, jak w przypadku aktów prawnych o wiążącym charakterze ${ }^{21}$. W dokumencie, będącym ewaluacją pierwszych partnerstw na rzecz mobilności podpisanych z Mołdawią i Republika Zielonego Przylądka, instytucja podkreśla ich elastyczność - mogą one szybko zostać dostosowane do aktualnych potrzeb partnerów ${ }^{22}$. Jednocześnie jako dokumenty o charakterze politycznym nie wymagaja ratyfikacji i implementacji w państwach uczestniczących w partnerstwie, co znacznie skraca czas wejścia w życie umów. W każdej chwili do projektu mogą dołączyć zainteresowane kraje, z czego skorzystała np. Holandia, która kilka miesięcy po podpisaniu deklaracji z Republiką Zielonego Przylądka dołączyła do partnerstwa.

${ }^{20}$ R. Parkes, Mobility Partnerships: valuable addition to the ENP repertoire? A checklist for revitalising ENP, German Institute for International and Security Affairs, Working Paper FG 1, No. 03/2009, SWP Berlin.

21 European Policy Center, Mobility partnerships - An effecitive tool for EU external migration policy?, http://www.epc.eu/events_rep_details.php?cat_id=6\&pub_id=2696 [dostęp: 25.01.2014].

22 European Commission, Commission Staff Working Document Mobility partnerships as a tool of the Global Approach to Migration, SEC(2009)1240, s. 4. 
Zdaniem Komisji podpisane umowy są najbardziej innowacyjnym i wysoko rozwiniętym instrumentem realizującym założenia globalnego podejścia do migracji. Ocenia się, że partnerstwa spełniają założenia i priorytety zarówno państw UE, jak i krajów partnerskich. Jedynym ryzykiem, jakie niesie ze soba ta forma współpracy, jest zebranie działań podejmowanych indywidualnie przez państwa członkowskie w ramach dotychczasowej współpracy i powtórzenie ich w partnerstwie. W ten sposób instrument UE staje się „zlepkiem” istniejących inicjatyw i pozbawiony zostaje wartości dodanej. Ten argument jest dość często przytaczany w literaturze, gdyż państwa członkowskie niechętnie dublują swoje działania, szczególnie w przypadku, kiedy istniejace formy współpracy dobrze funkcjonują ${ }^{23}$. W swojej ewaluacji partnerstw na rzecz mobilności Komisja podkreśla fakt, że mechanizm ten jest wszechstronny i kompleksowo odzwierciedla wszystkie elementy globalnego podejścia do migracji, podczas gdy stosowane do tej pory instrumenty koncentrowały się jedynie na jego wybranych aspektach ${ }^{24}$.

Zaletą partnerstw jest ich komplementarność z innymi politykami, instrumentami i działaniami UE w zakresie migracji oraz ich pozytywny wpływ na zacieśnianie więzi z państwami partnerskimi. Partnerstwa są uważane za platformę wspierająca przejrzyste, wspólne działanie państw członkowskich i instytucji europejskich - nie tylko Komisji, ale również agencji Frontex czy Europejskiej Fundacji Kształcenia. Wspólne działanie krajów UE w sferze migracji wzmacnia narodową politykę migracyjna, której realizacja wyłącznie na szczeblu krajowym jest coraz trudniejsza ${ }^{25}$. Ocena, jaka Komisja wystawia realizowanym umowom, jest więc zdecydowanie pozytywna, a instytucja wydaje się pełna optymizmu, jeżeli chodzi o przyszłość partnerstw. Omawiane instrumenty uważane są za projekty długofalowe, które będą ulegały dalszemu rozwojowi i coraz lepszemu dopasowaniu do aktualnych potrzeb zaangażowanych państw. Co więcej, partnerstwa wpisują się w aktualny, międzynarodowy dyskurs, w którym migracja łączona jest ze wspieraniem rozwoju państw trzecich. Są té̇ środkiem realizacji innej polityki, np. zagranicznej czy sassiedztwa UE.

Komisja Europejska koncentruje się głównie na pozytywnych aspektach partnerstw na rzecz mobilności, jednakże obiektywna ocena zawartych porozumień nie jest jednoznaczna. Przede wszystkim pojawia się pytanie o rzeczywistą promocję legalnej migracji do UE. Dość trudno jednoznacznie ocenić wpływ inicjatyw w zakresie legalnej migracji na rzeczywisty wzrost przemieszczeń o charakterze zarobkowym z krajów partnerskich do UE. Obecnie jedyną możliwością weryfikacji skuteczności partnerstw są dane statystyczne. Jest to metoda niedoskonała, gdyż nie można mieć pewności, w jakim stopniu do zmian w przypływie do państw członkowskich obywateli państw trzecich przyczyniły się podpisane umowy. Ponadto większość danych statystycznych

${ }^{23}$ N. Reslow, The New Politics of EU Migration Policy: Analysing the Decision-Making Process of the Mobility Partnerships, Maastricht University, Netherlands 2010, s. 17.

${ }^{24}$ European Commission, Commission Staff Working Document Mobility partnerships as a tool of the Global Approach to Migration, op. cit., s. 6.

${ }^{25} \mathrm{~N}$. Reslow, Explaining the development of EU migration policy: the case of Mobility Partnerships, Paper prepared for the fifth Pan-European Conference on EU Politics, Porto, Portugal, 23-26 June 2010, s. 4. 
nie odnotowuje migrantów tymczasowych. Mimo tych trudności warto przyjrzeć się statystykom odzwierciedlającym liczby migrantów w poszczególnych krajach. Analiza danych statystycznych Eurostatu dokonana przez Nastasję Reslow wskazuje na brak wpływu partnerstw podpisanych z Mołdawia, Armenia, Gruzją i Republika Zielonego Przylądka na liczbę wydawanych obywatelom tych krajów wiz krótkoterminowych czy zezwoleń pobytu w państwach członkowskich ${ }^{26}$.

Dane statystyczne przedstawione przez OECD pozwalają na wyciagnięcie podobnych wniosków odnośnie do zmian w liczbie imigrantów z Mołdawii, Republiki Zielonego Przylądka, Gruzji i Armenii, jakie nastapiły od momentu podpisania poszczególnych partnerstw do 2014 r. ${ }^{27}$ Podobnie jak w przypadku danych Eurostatu, trudno wskazać na jednoznaczny wpływ na skalę migracji do państw członkowskich będących stronami partnerstw. W przypadku Mołdawii jedynie w Niemczech odnotowano wzrost liczby imigrantów w latach 2008-2013 (699 osób w 2008, 1039 - w 2013). Pozostałe kraje UE odnotowały w tym czasie znaczace spadki, jeżeli chodzi o napływ obywateli Mołdawii (m.in. we Włoszech spadek z ok. 22 tys. w 2008 do 3,7 tys. w 2014). Podobnie wygląda sytuacja z obywatelami Republiki Zielonego Przylądka - wzrost napływu zarejestrowano we Francji, spadek w Hiszpanii i Portugalii. Tendencje wzrostowe bardziej wyraźne są w przypadku Gruzji, gdyż w większości krajów partnerskich zwiększyła się liczba imigrantów z tego kraju (szczególnie w Niemczech i Włoszech). Zróżnicowane tendencje widoczne są również w danych statystycznych dla Armenii. W kilku krajach członkowskich, w tym w Belgii, we Francji i w szczególności w Niemczech, liczba imigrantów z Armenii wzrosła od momentu podpisania partnerstwa na rzecz mobilności. Sa i takie kraje, jak Czechy i Polska, gdzie liczba ta spadła, oraz takie, które nie odnotowały większych zmian w liczbie obywateli pochodzaccych z Armenii (Włochy).

Trudno zatem mówić o rzeczywistym wpływie partnerstw na wzrost mobilności, przy czym podkreślić należy, że być może statystyki te ulegną zmianie w dłuższej perspektywie czasowej. Co więcej, na mobilność migrantów wpływ mają różne czynniki niezwiązane z podpisanymi deklaracjami, tj. sytuacja gospodarcza i polityczna, nastroje społeczne i wiele innych. To sprawia, że wiarygodne źródła wskazujące na bezpośredni wpływ podpisanych deklaracji na wzrost imigracji do państw członkowskich nie istnieja, co niestety komplikuje badania w tej sferze.

Mocnym zarzutem wobec partnerstw na rzecz mobilności jest zbyt duża koncentracja na narzuconym krajom trzecim przez państwa członkowskie obowiązku readmisji swoich obywateli i lepszej kontroli granic. Można odnieść wrażenie, że to readmisja i walka $\mathrm{z}$ nielegalną imigracja, a nie legalna imigracja czy mobilność stanowią trzon porozumień. Takie podejście wynika z faktu, że jedynie w taki sposób, tzn. oferując krajom partnerskim pewne ułatwienia

${ }^{26}$ N. Reslow, EU „Mobility” Partnerships: an initial assessment of implementation dynamics, „Politics and Governance”3(2), 2015, s. 119-120.

${ }_{27}$ Organisation for Economic Cooperation and Development, https://stats.oecd.org/Index. aspx?DataSetCode= MIG [dostęp: 6.10.2016]. 
i pomoc w zarządzaniu migracjami oraz mglistą obietnicę legalnej migracji, UE jest w stanie wyegzekwować zgodę na readmisję obywateli tych państw ${ }^{28}$. Nacisk na kwestie związane z readmisja jest przez UE motywowany obawa przed pozostaniem migrantów w państwach członkowskich i zwiększeniem skali nielegalnej migracji. To krajom Unii, zdecydowanie bardziej niż ich partnerom, zależy na porozumieniu w tej sprawie. Państwa trzecie nieprzychylnie nastawione są do warunku readmisji, w którym widzą wyłącznie korzyści dla $\mathrm{UE}^{29}$. Niechęć ta wynika z kosztów i obciążeń finansowych, jakie wiążą się z realizacją umów o readmisji. Takie działanie nie leży w interesie państw trzecich, których gospodarki korzystają z transferów pieniężnych wysyłanych przez migrantów niezależnie od tego, czy ich wyjazd ma charakter legalny, czy też nie. Anna Triandafyllidou słusznie zauważa, że trudno uwierzyć, aby kraje partnerskie były w stanie sprostać wygórowanym oczekiwaniom $\mathrm{UE}^{30}$. Długa lista wymagań, jakie państwa trzecie muszą spełnić, by zyskać „nagrodę" w postaci partnerstwa na rzecz mobilności, sprawia, że ich postanowienia mogą okazać się niemożliwe do zrealizowania. Wiele krajów Europy Wschodniej czy Afryki nie dysponuje wystarczajacym zapleczem administracyjnym, technicznym czy finansowym, by zagwarantować spełnienie nałożonych na nie zobowiązań. Powstaje więc pytanie, czy dobrym rozwiązaniem jest wykluczenie ze współpracy w ramach partnerstwa państw, które nie są w stanie sprostać tym wymaganiom. Może okazać się, że brak współdziałania w dziedzinie legalnej migracji będzie bardzo niekorzystny i zakończy się zwiększeniem nielegalnego napływu imigrantów.

Partnerstwa na rzecz mobilności, pomimo pozytywnie kojarzącej się nazwy, nie do końca oparte są na współpracy równych partnerów, którym przyświecaja te same cele ${ }^{31}$. Pozycja negocjacyjna państw europejskich jest z pewnością silniejsza, zwłaszcza jeśli do deklaracji przystępuje jednocześnie kilka czy kilkanaście państw UE. Zastanawiający jest w takim razie realny wkład państw trzecich w tworzenie projektów. Przykładowo Gruzja czy Maroko same nie zaproponowały żadnej inicjatywy zawartej w porozumieniu. Jean-Pierre P. Cassarino zwrócił uwagę na podwójna selektywność partnerstw ${ }^{32}$. Z jednej strony są one podpisywane z krajami, które zobowiązują się do realizacji warunków postawionych przez UE (dotyczących readmisji, ochrony granic itp.), z drugiej - dotyczą tylko niektórych kategorii imigrantów, którzy maja

${ }^{28}$ S. Carrera, R. Hernández i Sagrera, The Externalisation of the EU's Labour Immigration Policy. Towards Mobility or Insecurity Partnerships?, Centre for European Policy Studies, Working Document No. 321/2009, s. 19.

${ }_{29}$ J. P. Cassarino, Patterns of circular migration in the Euro-Mediterranean Area: implications for policy-making, CARIM 2008/29, s. 8.

${ }^{30}$ A. Triandafyllidou, Attemping the Impossible? The Prospects and Limits of Mobility Partnerships and Circular Migration, http://www.eliamep.gr/wp-content/uploads/en/2009/02/eliamepthesis-1-2009triandafylli dou.pdf [dostęp: 27.01.2014].

${ }^{31}$ R. Kunz, J. Maisenbacher, Beyond conditionality versus cooperation: power and resistance in the case of EU mobility partnerhips and Swiss migration partnerships, „Migration Studies” 1(2), 2013, s. 201.

32 J. P. Cassarino, EU Mobility Partnerships: Expression of a New Compromise, http://www. mi grationinformation.org/Feature/display.cfm?ID=741 [dostęp: 27.01.2014]. 
możliwość skorzystania z proponowanych form przyjazdu do państw Unii. Co więcej, postanowienia partnerstw zobowiązują tylko kraje członkowskie, które je podpisały, podczas gdy umowy o readmisji dotyczą całego terytorium $\mathrm{UE}^{33}$. Takie restrykcyjne podejście krajów UE do legalnej imigracji może wywołać efekt odwrotny i zwiększyć skalę migracji nielegalnej, tak jak to miało miejsce w przeszłości (program Bracero czy Gastarbeiter).

Fakt, że partnerstwa są instrumentem bardzo elastycznym, a uczestnictwo w nich zależy tylko i wyłącznie od woli państw członkowskich, z jednej strony może być zaleta, a z drugiej - może niekorzystnie wpływać na spójność i legitymizację polityki UE ${ }^{34}$. Wystarczy przyjrzeć się liczbie krajów Unii, które przystapiły do partnerstw. Najwięcej państw podpisało deklarację z Gruzja (16) i Mołdawią (15), podczas gdy zaledwie 5 krajów jest stroną w porozumieniu z Republiką Zielonego Przylądka ${ }^{35}$. Wyróżnić możemy kraje, które uczestniczą w kilku partnerstwach (Francja, Polska, Belgia), oraz takie, które nie biorą udziału w żadnym projekcie (Austria, Finlandia, Malta). Kraje decyduja się na podpisanie deklaracji, kiedy współpraca z danym państwem leży w ich narodowym interesie i zgodna jest z prowadzoną przez nie polityką ${ }^{36}$. Stąd wyraźny podział na państwa z południowych rejonów Europy zainteresowanych współpraca z krajami basenu Morza Śródziemnego i Afryki oraz państwa preferujące kooperację z regionem Europy Wschodniej ${ }^{37}$.

Wydaje się, że dobrowolne uczestnictwo w partnerstwach jest mimo wszystko dobrym rozwiązaniem. W takim przypadku udział biorą państwa, którym rzeczywiście zależy na współpracy, co znacznie zwiększa prawdopodobieństwo wywiązania się z podjętych zobowiązań. Aspektem, który został już wcześniej poruszony, jest rzeczywista wartość dodana partnerstw na rzecz mobilności. W przypadku deklaracji z Republiką Zielonego Przylądka, której sygnatariuszami sa Portugalia, Hiszpania, Francja i Luksemburg, większość inicjatyw zawartych w dokumencie jest propozycja któregoś z państw UE. Podkreślić należy, że inicjatywy te zostały zazwyczaj wyrażone już wcześniej w dwustronnych umowach zawartych pomiędzy państwami członkowskimi a Republika Zielonego Przylądka ${ }^{38}$. Pojawia się więc pytanie, w jakim stopniu jest to nowa forma multilateralnej współpracy, a w jakim po prostu zebranie w całość istniejących już projektów. Zastanawia również pominięcie w ostatnich deklaracjach propozycji konkretnych działań, do jakich zobowiązują się poszczególne państwa członkowskie.

${ }_{33}$ M. Martin, Extension des partenariats pour la mobilite avec les partenariats euro-mediterraneens, http://www.iemed.org/ observatori-fr/arees-danalisi/arxiusadjunts/ anuari/med.2012/ martin_fr.pdf [dostęp: 30.01.2014].

${ }_{34}$ S. Carrera, R. Hernández i Sagrera, op. cit., s. 36.

35 Holandia dołączyła do partnerstwa kilka miesięcy po jego podpisaniu.

${ }^{36}$ N. Reslow, The new politics of EU migration policy..., s. 23.

37 Ibidem, s. 22.

${ }_{38}$ M. H. Chou, M. Gibert, From Cotonou to Circular Migration: the EU, Senegal, and the „Agreement Duplicity”, Paper for „Migration: A World in Motion”, Maastricht, the Netherlands, 18-20 February 2010, s. 10. 


\title{
VI. ZAKOŃCZENIE
}

Współpraca w dziedzinie legalnej migracji może doprowadzić do lepszej koordynacji i spójności działań, ale przyglądając się podpisanym deklaracjom z pewnością nie możemy mówić o rewolucyjnych zmianach. Mimo wszystko państwa członkowskie są zainteresowane partnerstwami, wyrażają zgodę na uczestnictwo w nich, co pozwala przypuszczać, że spodziewają się jakichś korzyści. Dokładny monitoring i ewaluacja podpisanych partnerstw mogłyby rozwiać te wątpliwości. Dziwi więc podejście Komisji, która poza wczesną ewaluacją pierwszych dwóch deklaracji nie przedstawiła kolejnych raportów oceniających współpracę w ramach kolejnych partnerstw na rzecz mobilności. Ze względu na niezbyt zaawansowaną fazę realizacji umów i brak ich dokładnej oceny ze strony UE, trudno jednoznacznie wskazać na pozytywne efekty odnotowane przez uczestniczące w nich państwa. Pozostaje jednak mieć nadzieję, że w obliczu aktualnego kryzysu imigracyjnego Unia Europejska zacznie wreszcie podejmować konkretne działania w zakresie efektywnego zarządzania migracjami na poziomie europejskim. Analiza partnerstw na rzecz mobilności dokonana w niniejszym artykule wskazuje na niewykorzystany potencjał tego instrumentu, który mimo swoich słabych stron ma szansę pozytywnie wpłynać na europejską politykę imigracyjną.

dr Katarzyna A. Morawska

Muzeum Emigracji w Gdyni

k.morawska@muzeumemigracji.pl

\section{MOBILITY PARTNERSHIP AS AN INSTRUMENT \\ OF EUROPEAN UNION MIGRATION POLICY}

\author{
Summary
}

Migration policy is one of the competences that the European Union shares with Member States. Its main objective is to ensure the balanced approach to legal and illegal migration. Pursuant to Articles 79 and 80 of the Treaty on the Functioning of the European Union (TFEU) the EU has the right to take action aimed at the management of legal migration, whereby it is for Member States to decide on the number of migrant workers admitted to their territory. Since 2005 the EU has been implementing the Global Approach to Migration and Mobility which implies broad cooperation between Member States and sending countries in the field of migration. One of the elements of this approach is mobility partnerships which are special agreements between Member States and third countries concerning the management of population flows. These declarations are to improve migration management, to fight illegal migration and to promote legal migration to the EU. This article examines and evaluates declarations already signed and is an attempt to answer the question to what extent mobility partnerships may contribute to the growth of legal migration to the EU. 
